\title{
Trends in individual fat consumption in the UK 1900-1985
}

\author{
BY ALISON M. STEPHEN AND GLYNIS M. SIEBER \\ Division of Nutrition and Dietetics, College of Pharmacy, University of Saskatchewan, Saskatoon, \\ Saskatchewan S7N 0W0, Canada
}

(Received 7 August 1992 - Revised 13 August 1993 - Accepted 2 September 1993)

\begin{abstract}
Mortality from coronary heart disease is decreasing in a number of Western countries, although the pattern of the decrease differs from country to country. In the UK the mortality rate from coronary heart disease has declined since 1979, whereas in the USA mortality from this disease began to fall in 1968 and has continued since that time. Of many factors suggested as reasons for the decline, diet has been implicated, particularly dietary fat intake. However, food balance information suggests little change in fat intake. A recent examination of all published studies from the USA where individual fat intake has been reported indicated that fat intake in that country has fallen steadily since the mid 1960s. The present study describes a similar compilation of all published studies from the UK giving individual fat intakes. Ninety-seven studies, representing information for 24045 individuals, were used. Studies ranged in size from two to 3581 individuals and were drawn from all regions of the UK. Most studies used $7 \mathrm{~d}$ weighed intakes as the method of dietary assessment. Quadratic regression equations were applied to the fat intakes from all studies over time, with each study weighted by the number of individuals surveyed. Data were also divided into $\mathbf{1 0}$-year periods and weighted fat intakes for each decade were calculated. Data were expressed for all studies, then subdivided into males, females, children and the elderly. Comparisons between Scotland and the South-East of England were made. Results indicate that fat represented $30 \%$ or less of dietary energy in the UK until the 1930s, when it began to rise. This rise was curtailed by rationing during and after the Second World War, after which the rise continued, reaching a plateau of about $40 \%$ energy in the late $1950 \mathrm{~s}$, with little change until the late 1970s. Trends were similar in all age-groups, but less change has occurred recently in Scotland compared with South-East England. These results differ from the pattern in the USA and suggest that if greater changes in mortality from coronary heart disease are to be seen in the UK a greater reduction in dietary fat intake will have to occur.
\end{abstract}

Fat intake: Dietary trends: Coronary heart disease

The mortality rate for coronary heart disease has shown a different pattern of change in the last 25 years in the USA and the UK. In the USA, mortality from heart disease began to decline in 1968 and the decline has continued at an accelerated rate in the last 10 years (Kimm et al. 1983; Davis et al. 1985). In contrast to this, no change occurred in mortality rate from coronary heart disease in the UK in the 20 years before 1979 , when mortality began to decline and has continued to do so at a similar rate as in the USA in the 1970s (Heller et al. 1983).

Many reasons have been put forward for the decline in heart disease mortality, such as reduction in cigarette smoking, improved control of hypertension and improvements in medical treatment (Stallones, 1980; Levy, 1984). The role of diet is often discussed, particularly changes in the amount and type of fat, but because of inadequate information about consumption patterns in the last 80 years no conclusions have been reached about the contribution of dietary change to the decline. Recently, a study has been conducted whereby all individual assessments of fat intake in the USA during this century have been 
collated, and averages calculated for intakes of total fat and its constituents for each decade (Stephen \& Wald, 1990). These results showed that intake of total fat, as a percentage of energy, has declined in the USA from a plateau of $40-42 \%$ in the 1950 s and 1960 s to $36-37 \%$ in the early $1980 \mathrm{~s}$. The beginning of the decline in fat consumption occurred in the mid 1960s, preceding the fall in heart disease mortality. The main component of this fall was intake of saturated fat.

Because of the differences in pattern of mortality between the USA and the UK, a similar study to that carried out for the USA has been conducted for the UK. All studies from the UK where individual dietary intake of fat has been reported have been compiled. The present paper presents a summary of the analysis, the trends in individual fat consumption in the UK, and a comparison with the US data.

\section{METHODS}

The methods used in the present study to compile existing literature on individual fat intakes were very similar to those used in the comparative compilation for the USA (Stephen \& Wald, 1990). A search was made of all dietary studies conducted in the UK where fat intake was obtained from individual food records. Nutrition Abstracts and Reviews was examined for every entry under 'Dietary studies' from vol. 1 (1933) to vol. 59 (1989); a complete search was made of the indexes of both the British Journal of Nutrition (from vol. 1, 1947 to vol. 62, 1989) and the Journal of Human Nutrition (from vol. 1, 1947 (Nutrition) to vol. 43, 1989 (European Journal of Clinical Nutrition)). References in articles from these journals led to articles in medical journals, journals from other disciplines, government publications, particularly from the Department of Health and Social Security, and other special reports such as the MRC Special Report Series. Only studies of individual assessments were used, hence the National Food Survey data were not included.

Most studies included in the compilation were dietary surveys, but other types of study were also suitable, such as dietary assessment before an intervention protocol, or the dietary intake of a control group in a case-control study.

Data from all types of healthy individuals were used in the analysis, whether they were a random sample of a population or specific groups, like athletes, specific-income groups or occupations, or pregnant or lactating females. There is no convincing evidence that any of these conditions influences the proportions of the three major nutrients, protein, fat and carbohydrate, in the diet. Vegetarians were excluded since their diet is clearly different from that of non-vegetarians.

Studies conducted on groups living outside the UK, such as personnel on navy ships or tankers, or groups on expeditions, were excluded since the dietary choices were very restricted and were supplemented with foods obtained at foreign locations. Also excluded were studies conducted on individuals with medical conditions, even if it is not clear that the condition has an effect on dietary intake. Only results from healthy individuals were used.

\section{Age}

All ages were used, from 2 years upwards. Studies were considered together, irrespective of age, then were subdivided by age-group into: children 2-17 years, adult males 18-65 years, adult females $18-65$ years, and the elderly $65+$ years. For studies which did not give the age-range of their participants, ages were assigned based on available information such as terms like middle-aged (assigned 35-55 years), students (18-25 years), mothers (16-45 years). When no upper age was given, and the study clearly included the elderly, maximum age was taken to be 99 years. 


\section{Region}

All studies from England, Wales, Scotland and Northern Ireland were used. Studies from the Republic of Ireland were not included. Studies were subdivided into nine regions similar to those used in the National Food Survey, i.e. Scotland, North-West, North-East, West Midlands, East Midlands, South-East, South-West, Wales and Northern Ireland, and the number of studies from each region determined. Studies from all nine regions were analysed together, and then subdivided where there were sufficient studies to make this possible.

\section{Year of dietary assessment}

When the year of dietary assessment was not given, an estimate of assessment year was made based on length of time between assessment and publication where both were given, taking into account the fact that the time to publication has become longer as the century has progressed.

\section{Method of dietary assessment}

The method of dietary assessment used in each study was noted, with details of whether household measures or weighed intakes were used and the number of days for which the assessment was carried out.

\section{Use of studies calculated in man-years}

Many early studies carried out on whole families were reported in 'man-years' to take account of variation in energy intake before adulthood. In most cases the original data were not available. 'Man-year' values have been included in the analysis as reported. In these studies the number of family members was often not given; for these studies the number of subjects has been estimated from those publications where number of family members was given.

\section{Nutrient intakes}

The nutrient information used in this compilation was: (1) energy intake (most studies reported in this kcal; values have been converted to MJ by multiplying by $4 \cdot 18 / 1000)$; (2) total fat intake $(\mathrm{g})$; (3) percentage of energy as fat.

It was intended to analyse these studies for saturated, monounsaturated and polysaturated fat intakes, but only a very small number of studies reported this subdivision of fat intake. Type of fat, therefore, has not been included in the analysis.

\section{Analysis of data}

The data were first examined with subdivision by age or sex; for each study, the percentage of energy as fat $v$. year of dietary assessment was plotted. Both linear and quadratic regression equations were fitted to these data to get the best-fit line, with each study weighted by the number of participants. The data were also divided into 10 -year intervals, $1900-1909,1910-1919$ etc. The weighted mean percentage fat intake was calculated for each time-period. The weighted quadratic regressions and the weighted means for each decade for fat intake (as a percentage of energy) were then compared with the results for the USA.

After analysis of all the studies the data were subdivided by age and, for adults, also by sex. For adult males and females, values for energy $(\mathrm{MJ})$, total fat $(\mathrm{g})$ and fat as a percentage of energy were plotted and subdivided into 10-year intervals as described for all the studies.

The statistical significance of the linear and quadratic weighted regression lines and the significance between the UK and US 10-year averages were determined using analysis of variance. 
Table 1. Details of published studies from the UK used in the compilation* ${ }^{*}$

\begin{tabular}{lccccccc}
\hline Group & Sex & $\begin{array}{c}\text { Age-range } \\
\text { (years) }\end{array}$ & $\begin{array}{c}\text { No. of } \\
\text { studies }\end{array}$ & $\begin{array}{c}\text { Mean no. } \\
\text { in study }\end{array}$ & $\begin{array}{c}\text { Total no. } \\
\text { of subjects }\end{array}$ & $\begin{array}{c}\text { Mean minimum } \\
\text { age (years) }\end{array}$ & $\begin{array}{c}\text { Mean maximum } \\
\text { age (years) }\end{array}$ \\
\hline Children & $\mathrm{M} / \mathrm{F}$ & $2-17$ & 19 & 430 & 8170 & $7 \cdot 9$ & $12 \cdot 8$ \\
Adult males & $\mathrm{M}$ & $18-64$ & 26 & 104 & 2696 & $26 \cdot 5$ & $56 \cdot 4$ \\
Adult females & $\mathrm{F}$ & $18-64$ & 35 & 113 & 3949 & $20 \cdot 2$ & $52 \cdot 1$ \\
Elderly & $\mathrm{M} / \mathrm{F}$ & $65+$ & 15 & 154 & 2315 & $61 \cdot 6$ & $89 \cdot 7$ \\
Total & $\mathrm{M} / \mathrm{F}$ & $2-99$ & 97 & 248 & 24045 & $21 \cdot 8$ & $60 \cdot 3$ \\
\hline
\end{tabular}

* For details, see p. 776.

$\uparrow$ Numbers in subdivided groups do not add up to total numbers. Many studies did not give separate data for males and females.

\section{RESULTS}

Ninety-seven studies were identified with figures for individual fat consumption (Paton $e t$ al. 1902; Ferguson, 1916, 1919; Tully, 1921, 1924; Tully \& Urie, 1992; Bedale, 1923; Medical Research Council, 1924, 1926; Hill, 1925a, b; Orr \& Clark, 1930; Cathcart \& Murray, 1932, 1936; Clark, 1933; Widdowson, 1936; Widdowson \& McCance, 1936, 1942, 1945; Charles, 1937; Fry \& Myers, 1938; McCance et al. 1938; Khan, 1941; Widdowson \& Alington, 1941; Cameron \& Graham, 1944; Bransby \& Wagner, 1945; Bransby, 1946; Roscoe \& McKay, 1946; Pyke et al. 1947; Bransby et al. 1948a, b; Cook, 1948; Hobson, 1948; Berry et al. 1949; Kitchin et al. 1949; Bransby \& Osborne, 1953; Hobson et al. 1953; Bransby \& Fothergill, 1954; Keys \& Keys, 1954; Widdowson et al. 1954; Chappell, 1955; Hobson \& Pemberton, 1955, 1956; Durnin et al. 1957, 1961 a, b, c, 1974; Thomson, 1958, $1959 a, b$; Thomson \& Billewicz, 1961; Morris et al. 1963, 1977; Platt et al. 1964; Ministry of Health, 1968; Department of Health and Social Security, 1972, 1975; Exton-Smith et al. 1972; Neill \& Phillips, 1972; Cook et al. 1973; Macleod et al. 1974; Lonergan et al. 1975; Akinrefon, 1976; Black et al. 1976, 1984, 1985, 1986; Smithells et al. 1977; Darke et al. 1980 a, b; Bingham et al. 1981; Bull et al. 1982; Doyle et al. 1982; Thomson et al. 1982, 1985, 1988 a, b: Bird \& Elwood, 1983; Hackett et al. 1983, 1984a, b; Bull \& Barber, 1984; Fehily et al. 1984a, b, 1988; Roshanai \& Sanders, 1984; Barasi et al. 1985; Davies \& Holdsworth, 1985; Bull \& Wheeler, 1986; Cole-Hamilton et al. 1986; Crawford et al. 1986; Fehily \& Bird, 1986; Marr \& Heady, 1986; Stockley et al. 1986; Wise et al. 1986; Barker et al. 1988; Bradley \& Theobald, 1988; Cade, 1988; Cade et al. 1988; Department of Health Committee on Medical Aspects of Food Policy, 1989; Loughridge et al. 1989; Thompson et al. 1989). These studies represented information on 24045 individuals. Study size ranged from two to 3581 subjects, the mean number being 2489 , the median ninety-six. Fifty $(52 \%)$ of the studies had less than 100 subjects; four had greater than 1000 . Fourteen studies were conducted only on males, twenty only on females. The number of subjects in total, and in each of the subgroups, the mean number, and the mean age of each group are shown in Table 1.

\section{Dietary assessment and region}

The main method of dietary assessment was $7 \mathrm{~d}$ weighed intakes. Of the total ninety-seven studies, fifty-six were $7 \mathrm{~d}$ weighed intakes, five were $3 \mathrm{~d}$ weighed intakes, and eighteen were other forms of record for $3 \mathrm{~d}$ or greater. This is a very different result from the previous analysis of studies from the USA where $27 \%$ of studies were $24 \mathrm{~h}$ recall, and records, mainly conducted for 3 or $7 \mathrm{~d}$, using household measures (Stephen \& Wald, 1990). Although the 
Table 2. Mean intake of total fat as a percentage of energy for all studies divided into 10year periods from 1900 to $1985^{\dagger}$

(Means are weighted by the number of subjects in each study; because there were large numbers of subjects in some studies, statistical tests were carried out on data weighted by the rank order of each study)

\begin{tabular}{|c|c|c|c|c|c|c|}
\hline \multirow[b]{2}{*}{ Time-period } & \multicolumn{3}{|c|}{ UK data } & \multicolumn{3}{|c|}{ US data } \\
\hline & $\begin{array}{l}\text { No. of } \\
\text { studies }\end{array}$ & $\begin{array}{c}\text { No. of } \\
\text { subjects }\end{array}$ & $\begin{array}{c}\text { Fat } \\
(\% \text { energy })\end{array}$ & $\begin{array}{l}\text { No. of } \\
\text { studies }\end{array}$ & $\begin{array}{c}\text { No. of } \\
\text { subjects }\end{array}$ & $\begin{array}{c}\text { Fat } \\
(\% \text { energy })\end{array}$ \\
\hline $1900-09$ & 1 & 57 & $24 \cdot 6$ & - & - & - \\
\hline $1910-19$ & 3 & 348 & $24 \cdot 1$ & - & - & - \\
\hline $1920-29$ & 13 & 5220 & $25 \cdot 9$ & 2 & 148 & $35 \cdot 5 * * *$ \\
\hline $1930-39$ & 8 & 916 & $33 \cdot 1$ & 2 & 37 & $41 \cdot 2^{* * *}$ \\
\hline $1940-49$ & 15 & 2385 & $33 \cdot 2$ & 20 & 4178 & $37 \cdot 6^{* * *}$ \\
\hline $1950-59$ & 13 & 1568 & $38 \cdot 4$ & 46 & 20993 & $40 \cdot 5^{* * *}$ \\
\hline $1960-69$ & 10 & 3873 & $40 \cdot 1$ & 28 & 11239 & $39.9 * * *$ \\
\hline $1970-79$ & 4 & 2294 & $40 \cdot 3$ & 53 & 73499 & $37 \cdot 8 * * *$ \\
\hline $1980-85$ & 20 & 7384 & $38 \cdot 2$ & 20 & 1492 & $37 \cdot 5 * * *$ \\
\hline
\end{tabular}

Mean values were significantly different from those for UK subjects: ${ }^{* * *} P<0.001$.

$\dagger$ For details of studies used and analytical procedures, see pp. 776-777.

major types of dietary assessment are different in these two compilations of published work, there is no evidence from the literature that fat intake assessed by any one method is systematically different from fat intake assessed by another. While weighed intakes carried out over a period of time may more closely represent usual intake by an individual, the number of subjects in studies where this method has been used is generally much smaller than in studies using $24 \mathrm{~h}$ recall to assess diet, and average intake by the two methods is not very different. The different methods used are also random, as far as period of the century is concerned; there is no indication, for example, that all $7 \mathrm{~d}$ weighed intakes are early or late in the data set which might influence interpretation of results.

The number of studies for each region was: Scotland 33, North-East 6, North-West 0 , East Midlands 8, West Midlands 1, South-East 27, South-West 3, Wales 5, Northern Ireland 1. The high number of studies from Scotland (34\% of the total number) reflects the strong nutrition tradition in Scotland, not only at the Rowett Research Institute in Aberdeen but also in Glasgow and Edinburgh. The large number from the South-East reflects the high population and the concentration of nutrition research and education establishments in the South-East of England. Thirteen studies were collaborations between a number of centres in different areas of the country.

\section{Intake of fat as a percentage of energy}

The data for all ninety-seven studies, divided into 10 -year periods for fat intake as a percentage of energy, are given in Table 2. The means are weighted by the number of subjects in each study. It can be seen that fat was below $30 \%$ energy until the 1930 s, when it rose slightly until the end of the 1940s. In the 1950s, fat intake increased to a plateau of $40 \%$ energy, where it remained through the $1960 \mathrm{~s}$ and $1970 \mathrm{~s}$; a decline of $2 \%$ energy as fat has occurred in the $1980 \mathrm{~s}$. This pattern is more clearly seen when each individual study is plotted, percentage of energy as fat $v$. year of dietary assessment, as shown in Fig. 1.

These results differ from those found for the USA, which are also given in Table 2 . In the USA, fat intakes reached a slightly higher plateau (40-42\% energy) than in the UK, but 


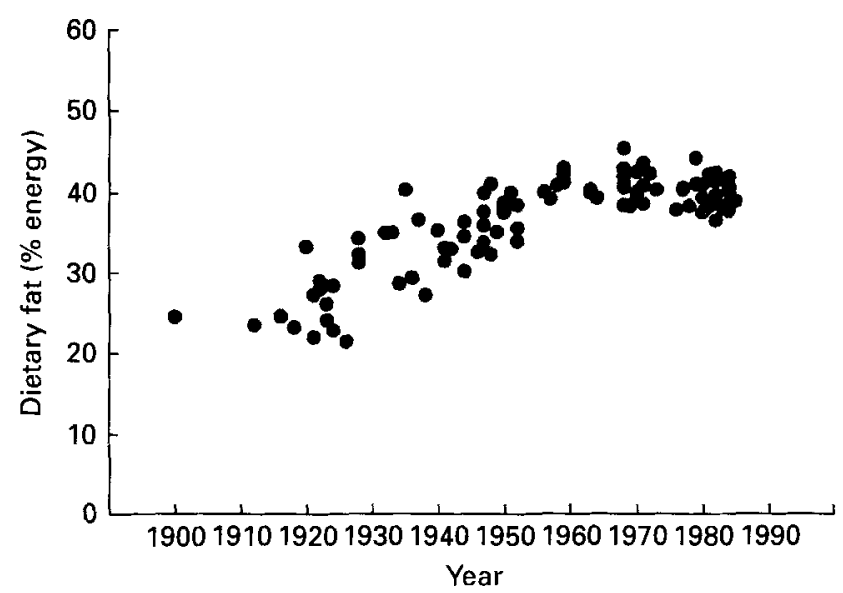

Fig. 1. Fat intake, as a percentage of energy intake, for all studies, including all age- and sex-groups $v$. year of dietary assessment. Each point represents a single study ( $n 97)$.

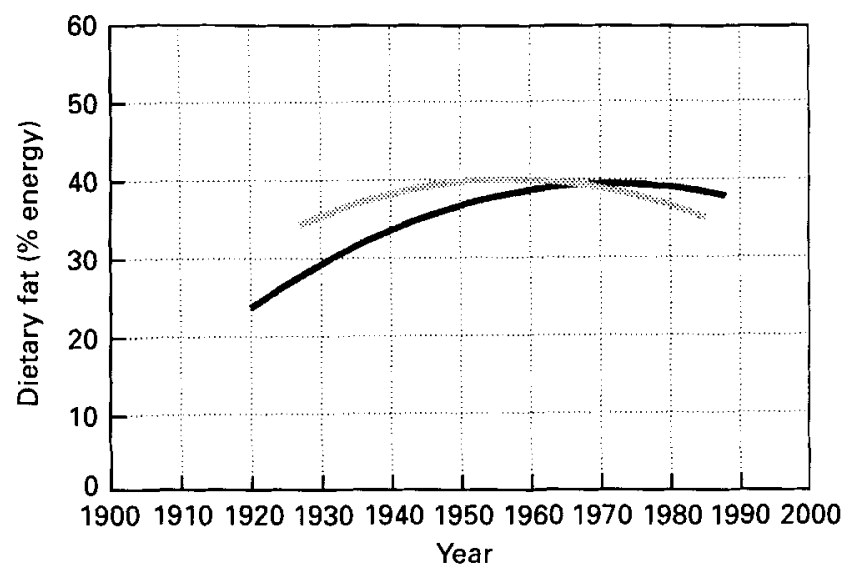

Fig. 2. Quadratic regression lines, weighted by the number of subjects in each study for the UK $(\square ; P<0.001$, $n$ 97) and the USA ( $\% ; P<0.001, n 171)$. The beginning of the decline in fat intake was approximately 1965 for the USA and 1975 for the UK.

have shown a decline beginning in the mid 1960s and continuing at an even faster rate since the mid 1970s (Stephen \& Wald, 1990).

The results from the UK and USA can also be examined by comparing the quadratic regression lines for each country, weighted by the numbers in each study. These are shown in Fig. 2 and clearly demonstrate a different trend in fat intake between the UK and USA. In the USA the fall in fat intake began in the mid 1960s, whereas for the UK it began in the mid 1970s. The plateau in each case was about $40 \%$ energy being derived from fat.

Intake of energy and total fat: males and females $18-65$ years

The intakes of energy, total fat $(\mathrm{g} / \mathrm{d})$ and fat as a percentage of energy in males and females aged $18-65$ years are given in Table 3 . These two subgroups show a similar pattern for percentage of energy from fat as do the data for all studies. They also demonstrate that mean energy intake has fallen during the course of the century, particularly in males, as has absolute fat intake $(\mathrm{g} / \mathrm{d})$. 
Table 3. Mean intakes of energy $(M J)$, total fat $(g)$ and fat $(\%$ energy) for males and females in the UK aged 18-65 years in 10-year periods from 1930 to $1985^{*}$

(All means are weighted by the number of subjects in each study)

\begin{tabular}{|c|c|c|c|c|c|c|c|c|}
\hline \multirow[b]{2}{*}{ Time-period } & \multicolumn{4}{|c|}{ Males } & \multicolumn{4}{|c|}{ Females } \\
\hline & $\begin{array}{l}\text { No. of } \\
\text { studies }\end{array}$ & $\begin{array}{l}\text { Energy } \\
(\mathrm{MJ})\end{array}$ & $\begin{array}{c}\text { Fat } \\
(\mathrm{g} / \mathrm{d})\end{array}$ & $\begin{array}{c}\text { Fat } \\
(\% \text { energy })\end{array}$ & $\begin{array}{l}\text { No. of } \\
\text { studies }\end{array}$ & $\begin{array}{c}\text { Energy } \\
(\mathrm{MJ})\end{array}$ & $\begin{array}{l}\text { Fat } \\
(\mathrm{g} / \mathrm{d})\end{array}$ & $\begin{array}{c}\text { Fat } \\
(\% \text { energy })\end{array}$ \\
\hline $1930-39$ & 4 & 12.90 & & 36.9 & 2 & $9 \cdot 22$ & & $38-8$ \\
\hline $1940 \quad 49$ & 7 & $12 \cdot 24$ & 105.9 & $34 \cdot 8$ & 4 & $8 \cdot 54$ & $79 \cdot 3$ & $32 \cdot 6$ \\
\hline $1950-59$ & 3 & 13.66 & $134 \cdot 2$ & $38 \cdot 4$ & 3 & $10 \cdot 23$ & $104 \cdot 6$ & $37 \cdot 3$ \\
\hline $1960-69$ & 1 & $11 \cdot 84$ & $126 \cdot 0$ & $40 \cdot 9$ & 1 & 9.00 & 98.0 & $40 \cdot 1$ \\
\hline $1970-79$ & 5 & 11.38 & $122 \cdot 1$ & $40 \cdot 1$ & 4 & 7.90 & $84 \cdot 7$ & $40-3$ \\
\hline $1980-85$ & 14 & $10 \cdot 57$ & $104 \cdot 5$ & $38 \cdot 9$ & 12 & $7 \cdot 23$ & 74.9 & $37 \cdot 2$ \\
\hline
\end{tabular}

* For details of studies used and analytical procedures, see pp. 776-777.

Table 4. Total fat intake in children (aged 2-17 years) and the elderly (aged $>65$ years) in the UK in 10-year periods from 1920 to 1985*

\begin{tabular}{|c|c|c|c|c|c|c|}
\hline \multirow[b]{2}{*}{ Time-period } & \multicolumn{3}{|c|}{ Children } & \multicolumn{3}{|c|}{ Elderly } \\
\hline & $\begin{array}{l}\text { No. of } \\
\text { studies }\end{array}$ & $\begin{array}{c}\text { No. of } \\
\text { subjects }\end{array}$ & $\begin{array}{c}\text { Fat } \\
(\% \text { energy })\end{array}$ & $\begin{array}{l}\text { No. of } \\
\text { studies }\end{array}$ & $\begin{array}{c}\text { No. of } \\
\text { subjects }\end{array}$ & $\begin{array}{c}\text { Fat } \\
(\% \text { energy })\end{array}$ \\
\hline $1920-29$ & 1 & 53 & $33 \cdot 2$ & - & - & - \\
\hline $1930-39$ & 2 & 103 & $35 \cdot 2$ & - & - & - \\
\hline $1940-49$ & 5 & 597 & $33 \cdot 7$ & 2 & 41 & $39 \cdot 7$ \\
\hline $1950-59$ & 1 & 277 & $39 \cdot 8$ & 6 & 460 & $38 \cdot 1$ \\
\hline $1960-69$ & 4 & 1831 & $38 \cdot 5$ & 4 & 1426 & 41.9 \\
\hline $1970-79$ & 4 & 1323 & 39.6 & 2 & 276 & $43 \cdot 3$ \\
\hline $1980-85$ & 2 & 3986 & $38 \cdot 2$ & 1 & 112 & $42 \cdot 0$ \\
\hline
\end{tabular}

* For details of studies used and analytical procedures, see pp. 776-777.

\section{Nutrient intakes in children and the elderly}

The number of studies conducted in children and the elderly is fewer than that in adult males and females (Table 4). The results for children show similar patterns as for all studies and adults; however, the results for elderly show a high fat intake throughout the century, without the fall in the 1980 s shown by all other groups.

\section{Fat intake by region}

Because of the large number of studies conducted in Scotland and the South-East, it was possible to compare these two regions. The 10-year averages are similar (Table 5), but the trends in fat intake, as shown by the weighted quadratic regressions (Fig. 3), show that fat intake in Scotland is not decreasing in the same way as has been demonstrated for all studies. The regression line for the South-East is very similar to that for all studies together.

\section{DISCUSSION}

Recent investigations have indicated that the consumption of total fat in the US diet has decreased since the mid 1960 s and by 1984 contributed 5-6\% less to total energy intake than in 1960-1965 (Stephen \& Wald, 1990). This fall in fat intake corresponds with the 
Table 5. Total fat intake in Scotland and the South-East of England in 10-year periods from 1920 to $1985^{*}$

\begin{tabular}{|c|c|c|c|c|c|c|}
\hline \multirow[b]{2}{*}{ Time-period } & \multicolumn{3}{|c|}{ Scotland } & \multicolumn{3}{|c|}{ South-East } \\
\hline & $\begin{array}{l}\text { No. of } \\
\text { studies }\end{array}$ & $\begin{array}{l}\text { No. of } \\
\text { subjects }\end{array}$ & $\begin{array}{c}\text { Fat } \\
(\% \text { energy })\end{array}$ & $\begin{array}{l}\text { No. of } \\
\text { studies }\end{array}$ & $\begin{array}{l}\text { No. of } \\
\text { subjects }\end{array}$ & $\begin{array}{c}\text { Fat } \\
(\% \text { energy })\end{array}$ \\
\hline $1920-29$ & 9 & 4179 & $25 \cdot 0$ & 2 & 610 & $27 \cdot 6$ \\
\hline $1930-39$ & 1 & 100 & 349 & 3 & 312 & $34 \cdot 5$ \\
\hline $1940-49$ & 4 & 728 & $33 \cdot 5$ & 6 & 214 & 34.8 \\
\hline $1950-59$ & 6 & 678 & $38 \cdot 6$ & 3 & 155 & $39 \cdot 3$ \\
\hline $1960-69$ & 2 & 667 & $40 \cdot 0$ & 4 & 949 & $38 \cdot 8$ \\
\hline $1970-79$ & 4 & 833 & $41 \cdot 3$ & 4 & 302 & $40 \cdot 8$ \\
\hline $1980-85$ & 3 & 382 & $38 \cdot 1$ & 5 & 218 & $40 \cdot 8$ \\
\hline
\end{tabular}

* For details of studies used and analytical procedures, see pp. 776-777.

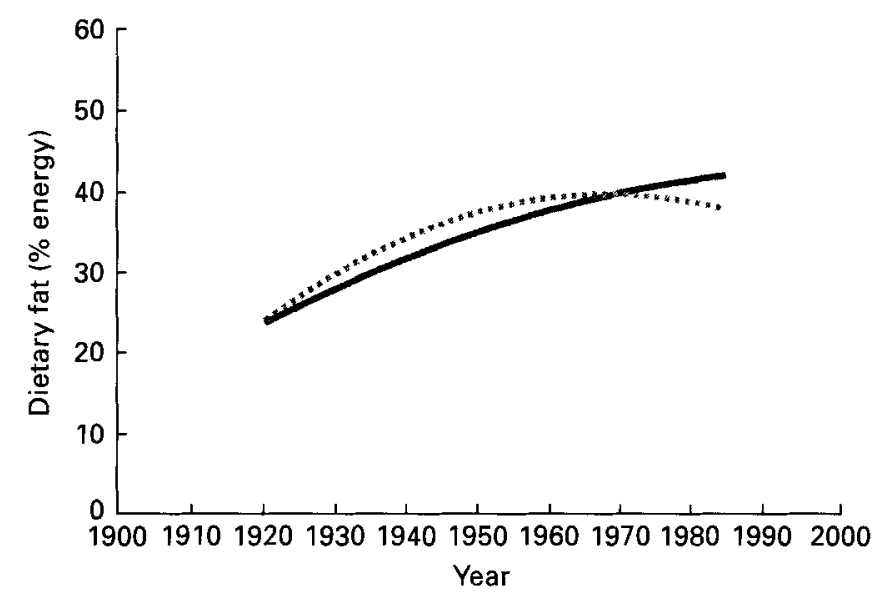

Fig. 3. Quadratic regression lines, weighted by the number of subjects in each study for Scotland ( - ; $P<0.001, n 33)$ and for the South-East of England (**:*; $P<0.001, n 27)$.

decline in heart disease mortality in the USA which began in 1968 and continues to fall each year, at a more accelerated rate in the late 1970s and 1980s than in the 1960s (Berry et al. 1949; Kimm et al. 1983; Davis et al. 1985). Such a dramatic decline in mortality rate has not taken place in the UK, although a reduction has occurred since 1979 (Heller et al. 1983). With a different pattern of mortality, it was of interest to know whether there was a different pattern of dietary intake, particularly of fat, between the USA and the UK.

There is no annual assessment of individual dietary intake in either country. The USA relies for trend information on the food supply values published by the US Department of Agriculture. These values do not include food wasted or spoiled or used for purposes other than human consumption and, therefore, do not represent food actually consumed. In the UK, annual assessment of dietary trends is carried out through the National Food Survey, a household purchase survey, conducted on 7000-8000 households each year. Although household surveys are at a closer level to the consumer than food supply, in that food wastage or spoilage at the production level is not included, they also do not represent food actually consumed because they only partially take account of wastage or spoilage in the household or food eaten away from home. Moreover, the National Food Survey was first 
carried out in 1947, and, therefore, nutrient intakes before that time are not available for comparison.

Because of the inadequacies of these methodologies, a study was undertaken to compile all investigations conducted in the UK during the 20th century in which individual dietary assessment was carried out and fat intake reported, and to compare these with equivalent results from the USA. Intake of fat is difficult to assess partially because of variations in the lean:fat ratio in meats. While it is recognized that individual studies may under- or over-represent true fat intakes because of methodological difficulties, this compilation is intended to overcome inaccuracies in individual studies by using as many sets of data as possible. Comparison of trends using only a small number of studies, even if they are individually large, is subject to greater error than consideration of all published work. It is also assumed that investigators have used the appropriate food composition tables, giving the composition of foods, particularly meats, for the period when they were consumed.

The results of compiling these studies indicate that fat intake as a percentage of energy rose in the UK during the early part of the century from a plateau at about $25 \%$ up to about $33 \%$ by the end of the 1930s. The rise occurring in the 1930s appears to have been halted to some extent by the Second World War and the rationing of food which took place during the entire decade of the 1940s, and into the early 1950 s for some items. Thereafter, the rise in fat intake continued to a plateau at about $40 \%$ energy, a level which was maintained until the mid to late 1970s when a decline began, continuing into the $1980 \mathrm{~s}$.

Results for children and adult males and females showed similar trends to all studies together, but results for the elderly showed little change in fat intake over the 25 years between 1960 and 1985. Although the results for the elderly are based on much smaller numbers and should be viewed with caution, they do suggest that this group in the population is making less change in its diet than the younger groups studied.

Current recommendations for most Western countries suggest that fat in the diet should provide 30\% energy (National Advisory Committee on Nutrition Education, 1983; American Heart Association, 1986; Health \& Welfare Canada, 1990). The present results indicate that in the UK before the $1930 \mathrm{~s}$, fat represented less than $30 \%$ energy, and that until the 1950 s it remained less than $35 \%$. It has been suggested that the recommendation of $30 \%$ is difficult to attain with today's food choices and, although it is true that there is considerably more variety in the diet in the latter half of the 20 th century than previously, it is clear from these early studies that a low-fat diet is possible. The intake of other major nutrients is not given in the present paper, but examination of the early studies indicates a very high carbohydrate intake, at about $60 \%$ energy, provided mainly by starch. Current recommendations also suggest increasing consumption of carbohydrate in the form of starch; ironically, it seems that the goals for the proportions of the major nutrients at the end of the century are closely represented by the diet consumed in the early part of the century.

The pattern of total fat intake in the UK is quite different from that found for the USA. As shown in Table 2, fat intake in the USA was significantly higher than in the UK from the 1930 s to the 1950 s. During the decade of the 1960 s, the levels were very similar but a decline has been seen in the USA since midway through that decade. This decline precedes the decline in heart disease mortality in that country by about 4 years. In the UK, a decline in mortality has occurred since 1979 , and this too is preceded by a fall in fat intake. Both the US and UK data, therefore, show a change in diet closely associated with mortality change, and preceding it by a similar period of time, namely 4-5 years.

In the USA there are regional variations in heart disease mortality (Kimm et al. 1983; Davis et al. 1985), but in the compilation of dietary studies there were insufficient from any one region to subdivide the studies this way. With the UK studies, however, there were a 
large number from both Scotland and the South-East, two areas with different mortality rates. The comparison of dietary trends for these two regions shows less change in Scotland than in the South-East, which suggests, as has been suspected, that the Scottish diet is changing less than that in the South.

Although the numerical differences may appear small, a 3-4\% change in the contribution of energy from fat is a considerable alteration of eating habits. It would include a conscious move by the consumer to eat lower-fat foods, to cut fat off meat, or to change cooking practices. It may also reflect changes in fat content of existing manufactured food products and the introduction of new lower-fat products. A lower-fat diet is also a consequence of eating a higher-fibre, higher-carbohydrate diet.

The US consumer is making many of these changes and has done so for two decades, with increasing enthusiasm. Low (2\%)-fat milk has been available in the USA since the 1960 s, whereas equivalent milk (semi-skimmed, $1.8 \%$ fat) was not available in the UK until 1983. Low-fat or 'lite' products have a continuing popularity in North America, whereas the British consumer appears to be more resistant to changes in traditional eating habits.

Diet, and particularly fat in the diet, are known risk factors for heart disease. The present results for the UK and their difference from those for the USA may serve to explain in part the relative changes in heart disease mortality in these two countries. If this is the case, and if heart disease rates are to fall further in the UK, dietary changes similar to those which have occurred in the USA will need to take place.

The authors are grateful for financial support from the NSERC Fund of the President of the University of Saskatchewan to carry out this work, and from the Heart and Stroke Foundation of Saskatchewan to present it at the American Heart Association meeting in 1990.

\section{REFERENCES}

Akinrefon, O. O. (1976). Nutrition survey of an old people's home in a London borough. Journal of Human Nutrition 30, 19-25.

American Heart Association (1986). Position statement. Dietary guidelines for healthy American adults. A statement for physicians and health professionals by the Nutrition Committee, American Heart Association. Circulation 74, 1465A-1468A.

Barasi, M. E., Phillips, K. M. \& Burr, M. L. (1985). A weighed dietary survey of women in South Wales. Human Nutrition: Applied Nutrition 39A, 189-194.

Barker, M. E., McKenna, P. G., Reid, N. G., Strain, J. J., Thompson, K. A., Williamson, A. P. \& Wright, M. E. (1988). A comparison of the PETRA food recording system with the conventional weighed inventory technique. Journal of Human Nutrition and Dietetics 1, 179-186.

Bedale, E. M. (1923). Energy expenditure and food requirements of children at school. Proceedings of the Royal Society B 94, 368-404.

Berry, W. T. C., Beveridge, J. B., Bransby, E. R., Chalmers, A. K., Needham, B. M., Magee, H. E., Townsend, H.S. \& Daubney, C. G. (1949). The diet, haemoglobin values and blood pressures of Olympic athletes. British Medical Journal 1, 300-304.

Bingham, S., McNeil, N. I. \& Cummings, J. H. (1981). The diet of individuals: A study of a randomly-chosen cross section of British adults in a Cambridgeshire village. British Journal of Nutrition 45, 23-35.

Bird, G. \& Elwood, P. C. (1983). The dietary intakes of subjects estimated from photographs compared with a weighed record. Human Nutrition: Applied Nutrition 37A, 470-473.

Black, A. E., Billewicz, W. Z. \& Thompson, A. M. (1976). The diets of preschool children in Newcastle Upon Tyne 1968-71. British Journal of Nutrition 35, 105-113.

Black, A. E., Ravenscroft, C. \& Paul, A. A. (1985). Footnotes to food tables: 1. Differences in nutrient intakes of dietitians as calculated from the DHSS food tables and the fourth edition of McCance and Widdowson's 'The Composition of Foods.' Human Nutrition: Applied Nutrition 39A, 9-18.

Black, A. E., Ravenscroft, C. \& Sims, A. J. (1984). The NACNE Report: are the dietary goals realistic? Comparisons with the dietary patterns of dietitians. Human Nutrition: Applied Nutrition 38A, 165-179.

Black, A. E., Wiles, S. J. \& Paul, A. A. (1986). The nutrient intakes of pregnant and lactating mothers of good socio-economic status in Cambridge, UK: Some implications for recommended daily allowances of minor nutrients. British Journal of Nutrition 56, 59-72. 
Bradley, A \& Theobald, A. (1988). The effects of dietary modification as defined by NACNE on the eating habits of 28 people. Joumal of Human Nutrition and Dietetics 1, 105-114.

Bransby, E. R. (1946). The diets of families with children in 1941. British Medical Journal 1, 832-835.

Bransby, E. R., Daubney, C. G. \& King, J. (1948a). Comparison of results obtained by different methods of individual dietary survey. British Journal of Nutrition 2, 89-110.

Bransby, E. R., Daubney, C. G. \& King, J. (1948b). Comparison of nutrient values of individual diets found by calculation from food tables and by chemical analysis. British Joumal of Nutrition 2, 232-236.

Bransby, E. R. \& Fothergill, J. E. (1954). The diets of young children. British Journal of Nutrition 8, $195-204$.

Bransby, E. R. \& Osborne, B. (1953). A social and food survey of the elderly, living alone or as married couples. British Journal of Nutrition 7, 160-180.

Bransby, E. R. \& Wagner, G. (1945). The diets of school children in two industrial towns. British Medical Journal 2, 682-685.

Bull, N. \& Barber, S. A. (1984). Food and nutrient intakes of vegetarians in Britain. Human Nutrition: Applied Nutrition 38A, 288-293.

Bull, N. L., Smart, G. A. \& Judson, H. (1982). Food and nutrient intakes on Westray in the Orkney Islands. Ecology of Food and Nutrition 12,97-101.

Bull, N. L. \& Wheeler, E. F. (1986). A study of different dietary survey methods among 30 civil servants. Human Nutrition: Applied Nutrition 40A, 60-66.

Cade, J. E. (1988). Are diet records using household measures comparable to weighed intakes? Journal of Human Nutrition and Dietetics 1, 171-178.

Cade, J. E., Barker, D. J. P., Margetts, B. M. \& Morris, J. A. (1988). Diet and inequalities in health in three English towns. British Medical Journal 296, 1359-1362.

Cameron, C. S. \& Graham, S. (1944). Antenatal diet and its influence on stillbirths and prematurity. Glasgow Medical Journal 24, 1-7.

Cathcart, E. P. \& Murray, A. M. T. (1932). Studies in Nutrition. An Inquiry into the Diet of Families in Cardiff and Reading. MRC Special Report Series no. 165. London: H.M. Stationery Office.

Cathcart, E. P. \& Murray, A. M. T. (1936). A Dietary Survey in Terms of the Actual Foodstuffs Consumed. MRC Special Report Series no. 218. London: H.M. Stationery Office.

Chappell, G. M. (1955). Long-term individual dietary surveys. British Journal of Nutrition 9, 323-339.

Charles, J. A. (1937). A study of the diets of 69 working class families in Newcastle Upon Tyne. Nutrition Abstracts \& Reviews 6, 1057.

Clark, M. L. (1933). Family diet coefficients. British Medical Journal 2, 977-979.

Cole-Hamilton, I., Gunner, K., Leverkus, C. \& Starr, J. (1986). A study among dietitians and adult members of their households of the practicalities and implications of following proposed dietary guidelines for the U.K. Human Nutrition: Applied Nutrition 40A, 365-389.

Cook, J., Altman, D. G., Moore, D. M. C., Topp, S. G., Holland, W. W. \& Elliott, A. (1973). A survey of the nutritional status of schoolchildren. Relation between nutrient intake and socio-economic factors. British Journal of Preventive and Social Medicine 27, 91-99.

Cook, R. P. (1948). The dietary intake of a class of students. British Medical Journal 2, 711

Crawford, M. A., Doyle, W., Craft, I. L. \& Laurance, B. M. (1986). A comparison of food intake during pregnancy and birthweight in high and low socioeconomic groups. Progress in Lipid Research 25, $249-254$.

Davis, W. B., Hayes, C. G., Knowles, M., Riggan, W. B., Van Braggen, J. \& Tyroler, H. A. (1985). Geographic variation in declining ischemic heart disease mortality in the United States 1968-1978. American Journal of Epidemiology 122, 657-672.

Darke, S. J., Disselduff, M. M. \& Try, G. P. (1980a). A nutrition survey of children from one-parent families in Newcastle Upon Tyne in 1970. British Journal of Nutrition 44, 237-241.

Darke, S. J., Disselduff, M. M. \& Try, G. P. (1980 b). Frequency distributions of mean daily intakes of food energy and selected nutrients obtained during nutrition surveys of different groups of people in Great Britain between 1968 and 1971. British Journal of Nutrition 44, 243-252.

Davies, L. \& Holdsworth, M. D. (1985). Nutrition and health at retirement age in the United Kingdom. Human Nutrition: Applied Nutrition 39A, 315-332.

Department of Health and Social Security (1972). A Nutrition Survey of the Elderly. Reports on Health and Social Subjects no. 3, pp. 1-101. London: H.M. Stationery Office,

Department of Health and Social Security (1975). A Nutrition Survey of Pre-school Children 1967-68. Report on Health and Social Subjects no. 10, pp. 1-51. London: H.M. Stationery Office.

Department of Health Committee on Medical Aspects of Food Policy (1989). The Diets of British Schoolchildren. Report on Health and Social Subjects no. 36, pp. 1-235. London: H.M. Stationery Office.

Doyle, W., Crawford, M. A., Laurance, B. M. \& Drury, P. (1982). Dietary survey during pregnancy in a low socio-economic group. Human Nutrition: Applied Nutrition 36A, 95-106.

Durnin, J. V. G. A., Blake, E. C., Allan, M. K., Shaw, E. J. \& Blair, S. (1961 a). Food intake and energy expenditure of elderly women with varying-sized families. Journal of Nutrition 75, 73-76.

Durnin, J. V. G. A., Blake, E. C., Allan, M. K., Shaw, E. J., Wilson, E. A., Blair, S. \& Yuill, S. A. (1961 b). The food intake and energy expenditure of some elderly men working in heavy and light engineering. British Journal of Nurition 15, 587-591. 
Durnin, J. V. G. A., Blake, E. C. \& Brockway, J. M. (1957). The energy expenditure and food intake of middleaged Glasgow housewives and their adult daughters. British Joumal of Nutrition 11, 85-94.

Durnin, J. V. G. A., Blake, E. C., Brockway, J. M. \& Drury, E. A. (1961c). The food intake and energy expenditure of elderly women living alone. British Journal of Nutrition 15, 499-506.

Durnin, J. V. G. A., Lonergan, M. E., Good, J. \& Ewan, A. (1974). A cross-sectional nutritional and anthropometric study, with an interval of 7 years, on 611 young adolescent schoolchildren. British Journal of Nutrition 32, 169-179.

Exton-Smith, A. N., Stanton, B. R. \& Windsor, A. C. M. (1972). Nutrition of Housebound Old People, pp. 5-23, 33-43. London: King Edward's Hospital Fund for London.

Fehily, A. M. \& Bird, G. (1986). The dietary intakes of women in Caerphilly, South Wales: A weighed and a photographic method compared. Human Nutrition: Applied Nutrition 40A, 300-307.

Fehily, A. M., Phillips, K. M. \& Sweetnam, P. M. (1984a). A weighed dietary survey of men in Caerphilly, South Wales. Human Nutrition: Applied Nutrition 38A, 270-276.

Fehily, A. M., Phillips, K. M. \& Yarnell, J. W. G. (1984b). Diet, smoking, social class, and body mass index in the Caerphilly heart disease study. American Journal of Clinical Nutrition 40, 827-833.

Fehily, A. M., Yarnell, J. W. G., Bolton, C. H. \& Butland, B. K. (1988). Dietary determinants of plasma lipids and lipoproteins: the Caerphilly study. European Journal of Clinical Nutrition 42, 405-413.

Ferguson, M. (1916). The family budgets and dietaries of forty labouring class families in Glasgow in wartime. Proceedings of Royal Society of Edinburgh 37, 117-136.

Ferguson, M. (1919). The diets of labouring class families during the course of the war. Journal of Hygiene 18, $409-416$

Fry, L. S. \& Myers, S. (1938). A physiological study of the diets of 15 rural workers' families in Essex. Public Health 51, 358-363.

Hackett, A. F., Rugg-Gunn, A. J. \& Appleton, D. R. (1983). Use of a dietary diary and interview to estimate the food intake of children. Human Nutrition: Applied Nutrition 37A, 293-300.

Hackett, A. F., Rugg-Gunn, A. J., Appleton, D. R., Eastoe, J. E. \& Jenkins, G. N. (1984a). A 2-year longitudinal nutritional survey of $\mathbf{4 0 5}$ Northumberland children initially aged 11.5 years. British Journal of Nutrition $\mathbf{5 1}$, $67-75$.

Hackett, A. F., Rugg-Gunn, A. J., Appleton, D. R., Parkin, J. M. \& Eastoe, J. E. (1984b). A two-year longitudinal study of dietary intake in relation to the growth of 405 English children initially aged 11-12 years. Annals of Human Biology 11, 545-553.

Health and Welfare Canada (1990). Nutrition Recommendations... A Call for Action. The Report of the Scientific Review. Ottawa: Canadian Government Publishing Centre

Heller, R. F., Hayward, D. \& Hobbs, M. S. T. (1983). Decline in rate of death from ischaemic heart disease in the United Kingdom. British Medical Journal 286, 260-262.

Hill, A. B. (1925a). Internal Migration and Its Effects upon the Death-rates: With Special Reference to the County of Essex. MRC Special Report Series no. 95. London: H.M. Stationery Office.

Hill, A. B. (1925b). A physiological and economic study of the diets of workers in rural areas as compared with those of workers resident in urban districts. Journal of Hygiene 24, 189-240.

Hobson, W. (1948). A dietary and clinical survey of pregnant women with particular reference to toxaemia of pregnancy. Journal of Hygiene 46, 198-216.

Hobson, W., Jordan, A. \& Roseman, C. (1953). Serum-cholesterol levels in elderly people living at home. Lancet ii, 961-964.

Hobson, W. \& Pemberton, J. (1955). The Health of the Elderly at Home. A Medical, Social and Dietary Study of Elderly People Living at Home in Sheffield, pp. 93-1 19. London: Butterworth \& Co.

Hobson, W. \& Pemberton, J. (1956). The health of the elderly at home. British Medical Journal 1, 587-593.

Keys, A. \& Keys, M. H. (1954). Serum cholesterol and the diet in clinically healthy men at Slough near London. British Journal of Nutrition 8, 138-146.

Khan, N. U. (1941). A study of the diet and social conditions of the working-class families in Newcastle Upon Tyne. Nutrition Abstracts and Reviews 11, 102.

Kimm, S. Y. S., Ornstein, S M., DeLong, E. R. \& Grufferman, S. (1983). Secular trends in ischemic heart disease mortality: regional variation. Circulation 68, 3-8.

Kitchin, A. H., Passmore, R., Pyke, M. \& Warnock, G. M. (1949). Studies of the diet of students at Edinburgh University. British Journal of Social Medicine 3, 10-28.

Levy, R. I. (1984). Causes of the decrease in cardiovascular mortality. American Journal of Cardiology 54, $7 \mathrm{C}-13 \mathrm{C}$.

Lonergan, M. E., Milne, J.S., Maule, M. M. \& Williamson, J. (1975). A dietary survey of older people in Edinburgh. British Journal of Nutrition 34, 517-527.

Loughridge, J. M., Walker, A. D., Sarsby, H. \& Shepherd, R. (1989). Foods eaten outside the home: nutrient contribution to total diet. Journal of Human Nutrition and Dietetics 2, 361-369.

McCance, R. A., Widdowson, E. M. \& Verdon-Roe, C. M. (1938). A study of English diets by the individual method. III. Pregnant women at different economic levels. Journal of Hygiene 38, 596-622.

Macleod, C. C., Judge, T. G. \& Caird, F. I. (1974). Nutrition of the elderly at home. I. Intakes of energy, protein, carbohydrates and fat. Age and Aging 3, 158-166. 
Marr, J. W. \& Heady, J. A. (1986). Within and between person variation in dietary surveys: number of days needed to classify individuals. Human Nutrition: Applied Nutrition 40A, 347-364.

Medical Research Council (1924). Report on the Nutrition of Miners and Their Families. MRC Special Report Series no. 87, pp. 20-33. London: H.M. Stationery Office.

Medical Research Council (1926). Poverty, Nutrition and Growth. Studies of Child Life in Cities and Rural Districts of Scotland. MRC Special Report Series no. 101. London: H.M. Stationery Office.

Ministry of Health (1968). A Pilot Survey of the Nutrition of Young Children in 1963. Reports on Public Health and Medical Subjects no. 118, pp. 1-49. London: H.M. Stationery Office.

Morris, J. N., Marr, J. W. \& Clayton, D. G. (1977). Diet and heart: a postscript. British Medical Journal 2 , $1307-1314$.

Morris, J. N., Marr, J. W., Heady, J. A., Mills, G. L. \& Pilkington, T. R. E. (1963). Diet and plasma cholesterol in 99 bank men. British Medical Journal 1, 571-576.

National Advisory Committee on Nutrition Education (1983). A Discussion Paper on Proposals for Nutritional Guidelines for Health Education in Britain. London: Health Education Council.

Neill, D. J. \& Phillips, H. I. B. (1972). The masticatory performance and dietary intake of elderly edentulous patients. Dental Practitioner 22, 384-389.

Orr, J. B. \& Clark, M. L. (1930). A dietary survey of six hundred and seven families in seven cities and towns in Scotland. Lancet ii, 594-598.

Paton, D. N., Dunlop, J. C. \& Inglis, E. (1902). A Study of the Diet of the Labouring Classes in Edinburgh, pp. 1-104. Edinburgh: Otto Schulze \& Co.

Platt, B. S., Gray, P. G., Parr, E., Baines, A. H. J., Clayton, S., Hobson, E. A., Hollingsworth, D. F., Berry, W. T. C. \& Washington, E. (1964). The food purchases of elderly women living alone: a statistical inconsistency and its investigation. British Journal of Nutrition 18, 413-429.

Pyke, M., Harrison, R., Holmes, S. \& Chamberlain, K. (1947). Nutritional value of diets eaten by old people in London. Lancet 253, 461-464.

Roscoe, M. H. \& McKay, H. S. (1946). A dietary survey of pregnant women and school children in Edinburgh. Edinburgh Medical Journal 53, 565-573.

Roshanai, F. \& Sanders, T. A. B. (1984). Assessment of fatty acid intakes in vegans and omnivores. Human Nutrition: Applied Nutrition 38A, 345-354.

Smithells, R. W., Ankers, C., Carver, M. E., Lennon, D., Schorah, C. J. \& Sheppard, S. (1977). Maternal nutrition in early pregnancy. British Journal of Nutrition 38, 497-506.

Stallones, R. A. (1980). The rise and fall of ischematic heart disease. Scientific American 243, 43-49.

Stephen, A. M. \& Wald, N. J. (1990). Trends in individual consumption of dietary fat in the United States 1920-1984. American Journal of Clinical Nutrition 52, 457-469.

Stockley, L., Hurren, C. A., Chapman, R. I., Broadhurst, A. J. \& Jones, F. A. (1986). Energy, protein and fat intake estimated using a food recording electronic device compared with a weighed diary. Human Nutrition: Applied Nutrition 40A, 19-23.

Thompson, B., Skipper, D., Fraser, C., Hewitt, A. \& Hunter, D. (1989). Dietary intake of Aberdeen primigravidae in 1950/51 and 1984/85. Journal of Human Nutrition and Dietetics 2, 345-359.

Thomson, A. M. (1958). Diet in pregnancy. 1. Dietary survey technique and the nutritive value of diets taken by primigravidae. British Journal of Nutrition 12, 446-461.

Thomson, A. M. (1959a). Diet in pregnancy. 2. Assessment of the nutritive value of diets, especially in relation to differences between social classes. British Journal of Nutrition 13, 190-204.

Thomson, A. M. $(1959 \mathrm{~b})$. Diet in pregnancy. 3. Diet in relation to the course and outcome of pregnancy. British Journal of Nutrition 13,509-525.

Thomson, A. M. \& Billewicz, W. Z. (1961). Height, weight and food intake in man. British Journal of Nutrition 15, 241-252.

Thomson, M., Elton, R. A., Fulton, M., Brown, S., Wood, D. A. \& Oliver, M. F. (1988a). Individual variation in the dietary intake of a group of Scottish men. Journal of Human Nutrition and Dietetics 1, 47-57.

Thomson, M.,Fulton, M., Elton, R. A., Brown, S., Wood, D. A. \& Oliver, M. F. (1988b). Alcohol consumption and nutrient intake in middle-aged Scottish men. American Journal of Clinical Nutrition 47, $139-145$.

Thomson, M., Fulton, M., Wood, D. A., Brown, S., Elton, R. A., Birtwhistle, A. \& Oliver, M. F. (1985). A comparison of the nutrient intake of some Scotsmen with dietary recommendations. Human Nutrition: Applied Nutrition 39A, 443-455.

Thomson, M., Logan, R. L., Sharman, M., Lockerbie, L., Riemersma, R. A. \& Oliver, M. F. (1982). Dietary survey in 40-year-old Edinburgh men. Human Nutrition: Applied Nutrition 36A, 272-280.

Tully, A. M. T. (1921). A study of the nutrition and economic conditions of working class families in Glasgow in April 1921. Lancet i, 57-59.

Tully, A. M. T. (1924). Artisan families in Glasgow. Glasgow Medical Journal, 101, 1-3.

Tully, A. M. T. \& Urie, E. M. (1922). Study of diets and economic conditions of labouring class families in Glasgow in June 1922. Glasgow Medical Journal 98, 353-368.

Widdowson, E. M. (1936). A study of English diets by the individual method. I. Men. Journal of Hygiene 36, $269-292$.

Widdowson, E. M. \& Alington, B. K. (1941). Middle-class diets in peace and war. Lancet ii, 361-365. 
Widdowson, E. M., Edholm, O. G. \& McCance, R. A. (1954). The food intake and energy expenditure of cadets in training. British Journal of Nutrition 8, 147-155.

Widdowson, E. M. \& McCance, R. A. (1936). A study of English diets by the individual method. II. Women. Journal of Hygiene 36, 293-309.

Widdowson, E. M. \& McCance, R. A. (1942). The war and school-boys' food. Lancet ii, 689-692.

Widdowson, E. M. \& McCance, R. A. (1945). Individual dietary surveys. Proceedings of the Nutrition Society 3 , 110-114.

Wise, A., Lockie, G. M. \& Liddell, J. A. (1986). Effective ways of reducing saturated fat intake. Health Education Journal 45, $210-214$. 